\section{The Security System of the United Nations (A Theoretical Approach)}

\author{
Katarzyna Czajkowska \\ Andrzej Frycz Modrzewski Krakow University (AFMKU) \\ Faculty of International Relations \\ katarzyna.czajkowska.1983@tlen.pl
}

\section{SUMMARY}

In contemporary world, influenced by globalization, security is one of the most discussed issues. It is almost commonly accepted that security should be regulated within some kind of international system. What should be agreed on are the nature of subjects within the system, the kind of resources, ways to control it and finally, how to achieve an agreement within the system's framework. Thus the objective of this article is to show the axiological premises that underlie normative regulations on the above issues. Significant diversion in this sphere is observed within the Organization of United Nations. The following article analyses the UN documents, with a particular emphasis on the Millennium documents, determining the long-term perspective of actions. The article shall also try to define the issues not covered in the UN regulations and determine what dilemmas UN unsuccessfully tries to tackle.

Keywords: security system, United Nations, theoretical approach

\section{INTRODUCTION}

In today's world, where transcontinental mass migrations, electronic exchange of the latest technologies and disasters, the international security has ceased to be just a question of maintaining or not maintaining peace. Civil wars, terrorist attacks and armament, as well as unemployment, production inefficiency, political absence, require the world community taking actions, not necessarily the military ones. The debate on normative regulations of the world order is constantly accompanied by dilemmas of its objective and subjective scope. The idea of this paper is that the shaping of this world order can be attributed to certain constant characteristics. This world order evolves within (to certain extend) a mature international community, which aim is to eliminate the threat of a global conflict. The participants of this community, not forgetting about the local perspective, see the need to carry out tasks on a global scale.

According to the report by the International Threat Management, even the most developed country has to cooperate with other countries alike in order to secure its own safety. Even though so many actors of international relations are engaged into the debate on international security, quite often it leads them to different conclusions, mainly dictated by immediate issues and national interests. The Organisation of United Nations, given the scale of its impact, available resources and legal ways of using them, should play a role of an arbiter and an authority in these polemics (A Plan for Action..., 2008). This article aims to analyze the UN views on the axiological premises of the world security, which, inevitably will be defined on the basis of the normative regulations set by the Organisation.

The United Nations Charter, points to the world peace, universal progress and the respect for dignity of the human person as the bases for the international security system (Charter of the United Nations..., 1945). These goals seem to be unquestionable as for their priority; considering the scale of the UN authority, we can also assume they are universally accepted (Balaban, 2005). It is not the case with the means of achieving these objectives, which, even though literally expressed in the Charter, are not co clear in practice. Doubts arise at institutional, legal and perhaps above all, axiological level. As noted by Zieba: „the universal security system struggles to achieve political consensus both in defining the threats and in taking appropriate measures to respond" (Zięba, 2006).

Especially in recent years, the evolution of premises underlying the doctrine of UN international security accelerated. In the last decade axionormative bases of this system were profoundly reassessed in order to enhance its functionality. First of all there is a matter of identifying the subjects of security system: whether they should be states, organisations or individuals. Second question regards the nature of the system: whether it should be based on material or social resources. The third issue refers to different ways to control the system: whether it should be based on the impact of unilateral authority or the collective management by all members of the system. Fourth, the discussion concerns the effectiveness of the system: whether it should stem from general consensus as to its principles, whether it comes from a top-down obligation under the threat of some sanctions.

\section{IDENTIFICATION OF THE ACTORS IN THE UN SECURITY SYSTEM}

As Baylis and. Smith mention the security means the freedom of the subjects from the threat against their basic values (Baylis and Smith, 2008). The difficulty arises, however, when defining these entities. Apart from circumstances of an external nature, the character of the subject - individual, national or international - is determined by the range of values which are taken into account. Fredman stated that ,in the world where polarisation rapidly grows, violence became simultaneously global and local and it's not about wars between countries any more but conflicts below the state level which have global connections and sources of funding" 
(Friedman, 2003). According to Czaputowicz geospatial aspect of security reaches both global and individual dimension. An attempt to take into consideration both these dimensions simultaneously makes all political decisions inadequate and hence ineffective (Czaputowicz, 2005).

The United Nations, in order to be seen as an arbiter of that order, must first overcome both asymmetry and lack of democracy in the international reality and on the other hand its total unpredictability and non-transparency. According to Czaja UN's biggest problem is the fact that in its legislation it doesn't recognise the non-state actors. They often have a higher GDP, better resources, and greater military potential and political ambitions than many countries (Czaja, 2003). Bailes said that the future importance of the UN depends on defining its international position and relationship with the USA (Bailes, 2004). The character of the UN-USA relationship often referred to as „Iraqi syndrome”, stems from exposing the institutional and authoritative weakness of the UN and what is more, a serious damage to its international authority.

The UN 2000 Millennium Declaration points out that the subjects of international relations are not only countries but also non-governmental organisations and all kinds of large associations that constitute a civil society. The Declaration says: „Responsibility for managing (...) threats to international peace and security, must be shared among the nations of the world and should be exercised multilaterally" (United Nations Millennium Declaration..., 2000). 2003 Report of High-level Panel indicates that political, social groups of criminal character can not be ignored as those, even though are not accepted due to the character of their activity, they still are the actors of international community (A More Secure World..., 2004).

In 1999, at the World Economy Forum in Davos, the Secretary General proposed the conclusion of a "global agreement" between the UN and the circles of international business, ,, as they like any other, are able to guarantee worker's rights, contribute to the improvement of environment and recognise the needs and aspirations of people" (Heinrich-Hamera, 2004). It does not mean that the activities of international business are fully accepted by all members of UN. Developed countries protested against the 2000 Resolution speaking about the negative impact of globalisation on the condition of developing countries (Role of the United Nations..., 1999). The more challenges however the Organisation is faced with, the smaller are its financial resources, the easier it accepts regional cooperation (Simonides, 2004).

The contemporary international order is cocreated by information communities led by the existing physical facilities such as media or logistic centres. In the near future, according to Strycharz and. Cilecki, information security will become one of the most critical international issues leaving past threats, such as the military ones, far behind (Strycharz and Cilecki, 2003). In virtual space new problems arise such as cyber-terrorism, information constraint and new class divisions onto technological underclass and aristocracy. Expressing its view in the 1998 Resolution, the UN states that the access to international information sharing and the progress in the implementation of new technologies constitutes one of the key factors to the security of countries and their citizens (Developments in the field..., 1999).

\section{CHARACTERISTIC OF RESOURCES OF THE UN SECURITY SYSTEM}

In accordance with the premises of the "theory of collective security" the security does not depend on the idea of balance of powers but a collective power coming from the unity of values and norms. At this point appears a trap of disregard for the autonomy of the subject being part of the system. There is no doubt that for those who are threatened by a formal or informal military attack, the most important will be military potential. These subjects will consider the concluded agreements in the context of the balance of accumulated military power. Next, there will be subjects weakened by famine, epidemics and natural disasters, for which an ally will be a party providing them with an immediate help, not necessarily corresponding in terms of social and political system. The subjects who struggle with unemployment, production inefficiency and low political sharing, will compensate their problems by cooperating with partners of similar direction in industrial, financial, political and social development (Keohane, 2002).

In terms of system resources, UN seems to be making major evaluations. Classic system of UN security envisaged the establishment of troops under UN command which would be there to help solve conflicts (Berdal, 1995). Nowadays military intervention is justified when all other means have been used, the situation poses a direct threat to human rights, the interested parties have been consulted and the intervention has a chance to solve the problem (Evans, 1994). Peaceful UN operations which involve military forces have been subjected to such normative limitations, that in practice they may be impossible to implement. Quoting Koziej: ,in the changing world, the preventive strategy and operations are justified from logical and procedural point of view. The only thing that is left to do is to make them justified from legal and political point of view" (Koziej, 2003).

In the early 90's Boutros-Ghali in the Agenda for Peace launched a functional and objective reform of at the time current system. The main objective of interventions was not the security of the state itself, but its components, and strengthening ,social, political and economical infrastructure" became a priority (Butros-Ghali, 1992). Greater emphasis was also placed on peaceful means of conflict solving. Agenda for Peace, 1992 introduces the instruments of preventive deployment, peacekeeping and enforcement of peace, which allow the use of military forces, but only after the exhaustion of all other means and while maintaining impartiality, transparency and legality (Skowroński, 1997). 
With the publication of UNDP in 1994 the UN began to place greater emphasis on human resources as the basis of international security system. According to Frechette's statement from 1999, security means that ,those living anywhere on earth have sufficient resources to feed their families, have place where they can find shelter, can receive medical help and education, are provided with protection against natural and military hazards and live under the rule of those who do not persecute their citizens but are in power with their acceptance" (Deputy Secretary-General..., 1999). General Secretary Annan made human security one of the cornerstones of his rhetoric. His concept is to give higher priority to the safety of individuals rather than the security of state (Report of the SecretaryGeneral..., 2000).

2000 Millennium Report, next to the epidemiological prevention, battling poverty and fight against various threats highlights the need of general access to education, access to information and freedom of speech (United Nations Millennium Declaration..., 2000). ICISS Report of 2002 also stated that in the era of threats of mainly economic, social and political nature rather than military, it is individuals and social groups, not states, who should be equipped in instruments of defence against these threats (Rotfeld, 2005). In the Social Development Report from 2005 the states were accused of incompetent policies on the implementation of the MDGs and submission immediate interests and „great politics" over the fate of their citizens (Human Development Report..., 2005). At the same time there appeared an issue of proportion in the UN policies, which by putting human safety first depreciates the fundamental principle of state sovereignty (Thomas and Tow, 2002).

\section{THE UN SECURITY CONTROL SYSTEM}

Most scholars are agreed on the fact that since the end of the war we are still in a transitional phase and a new word order has not been established yet. Meanwhile, the critics of post-Cold War neoliberalism believe that the new system has been created and within a few years exhausted its possibilities" (Węgrzyn, 2006). According to Kuźniar, contours of a new international order escape every attempt to grasp their theoretical explanation (Kuźniar, 2005). In the discussion on the shape of world order take part not only the traditional participants of international relations, but also organisations, circles, factions and even individual members of the international public opinion. It therefore appears that we are dealing with the environment where there is no authority or decisionmaking model applying to the supranational level.

Assuming that the bipolar security system ended two decades ago, and unilateral system embodied in the literature by the United States is not as effective as it could be expected, it would be advised to move towards the concept of global governance. This system would preclude the dominance of one subject of international community over the others, reduce undemocratic tendencies and ensure the balance between interests and needs of its participants. Ideally, such a system would be based on the principles expressed by Naidu: no use of force, collective management, equality of the parties and the stability of the system (Naidu, 1974).

The method of shaping the contemporary world order shows two tendencies which in the absence of a global conflict or disaster will not let it break down or reverse in its evolution (Łoś-Nowak, 2002). First of all it is an order shaped in conditions of peace. Secondly, it is shaped in large part on the basis of the intra-existential theories which declare its subjects being not single countries but their conglomerates. The United Nations seem to be moving towards such a Pax Consortis - a multi-component coalition of equal partners bearing the same level of responsibility (Malendowski, 2000). SecretaryGeneral Report from 2005 recognises the need of broad, deep and sustained cooperation of all entities constituting the system (In Larger Freedom..., 2005).

The Organisation, as the representative of its members rather than an independent body, can only passively watch any insubordination of the Kyoto Treaty, the refusal to pay contributions or refusal to submit to the jurisdiction of the International Criminal Court. Consensus on the multilateral security management is not synonymous with the identification of management subjects. Should only countries be represented there or organisations of a different nature too? If states, should they be those equipped in the means of real influence or those to whom these decisions refer? If organisations, then of what nature? As the security system is being diversified, should not we establish an entirely separate body which would be equipped in competencies necessary to manage the system on a global level? (Rudnicki, 2004)

The adoption of the principle of "responsibility for protection" in the final document of 2005 Summit, meaning the possibility for the UN to take over the defence of citizens against all kinds of threats, if the country, which they reside, is not able to do so, is a big break through (In Larger Freedom..., 2005). To a large extend this rule makes the UN independent from the individual interests of its members. The authors of the 1995 report "Our Global Neighbourhood" stated that the world clearly entered a multilateral phase; however, it still needs a central management centre (Global Governance..., 1995).

\section{CONDITIONS OF THE EFFECTIVENESS OF UN SECURITY SYSTEM}

For the collective managements system to function in a global scale, must be met several conditions of political, economic and social nature. A basic condition for its functioning, however, is the tendency of its participants to voluntarily adapt international law and create international political structures. As Evans said „, building peace requires to 
a large extend doing exactly the same thing as civilised society should do anyway, creating effective regulatory systems, mechanisms of resolving conflicts and cooperative solutions. [...] Usually, however, the above measures, although their intrinsic values are appreciated, are not perceived clearly enough as an integral component of efforts to achieve and maintain the peace and security" (Evans, 1994).

2000 Millennium Declaration lists as the basic principles of international relations: freedom, equality, solidarity, tolerance, respect for nature and shared responsibility (United Nations Millennium Declaration..., 2000). It should be noted, however, that these are no longer the same principles on which the UN was founded. As pointed out by Orbik, the Charter has been formulated to be the universal basis for world order. Therefore, all of its provisions should correspond to some universal morality. Otherwise, it will be observed only as long as a force exerted to compel obedience exists (Orbik, 2005).

Zięba draws attention to the phenomenon of ,selective multilateralism". According to him, it occurs when countries agree on the basic principles of a system, mainly on the fact that the system should exist, whilst picturing this system in various ways (Zięba, 2006). Although all members of the UN unanimously adopted the UN Global CounterTerrorism Strategy in 2006, the very definition of terrorism has been formulated so broadly that in practice it may lead to the members' passivity or, due to the variety of interpretations, may result in a deadlock (The United Nations..., 2006). For instance, in order to effectively combat the phenomenon of terrorism, UN must overcome at least two problems. First, of psychological nature, stems from an unequal sense of security. Second, of institutional nature, has its roots in the fact that the UN can rely solely on interstate cooperation, whilst acts of terrorism are undertaken by supra-state subjects (Frańczak, 2004).

In the Summary of 2005 World Summit, Member States affirmed that ,all provisions of the United Nations Charter are sufficient to achieve the objectives of the Organisation" (In Larger Freedom..., 2005). As a consequence, the UN needs to rely on re-interpretation of existing regulations even if new circumstances occur. Owing to the lack of a body authorised to provide binding legal interpretation, the UN decided to seek solution to this problem through liberal interpretation, i.e. depending on the circumstances and decisions of the subjects concerned. On one hand it added to the UN's flexibility, on the other hand, however, it led to an identity crisis (Popiuk-Rysińska, 1995).

The document summarizing the 2005 emphasized that ,the principles of democracy and human rights must be respected in every country regardless of the nationality of its civilisation" (In Larger Freedom..., 2005). At the same time it was recognised that there is no single model of democracy belonging to one particular country or region. The UN, at least in the sphere of declarations, recognises pluralism of values and attitudes of its members. As formulated by
Legault, the UN Charter is unique; it is a ,living document". This means that its regulations should not be taken literally. Instead, they must be read according to the interpretation of all current documents both national and international (ŁośNowak, 2005).

\section{CONCLUSIONS}

Recalling the definition used by the participants of the UN forum: ,security is a condition in which individual countries recognise they are not threatened by a military attack, political pressure or economic coercion and they are able to freely pursue chosen objectives of development and progress. International security is therefore the result and the sum of the safety of all and each countries and that is why it can not be achieved otherwise than by full co-operation" (Malendowski, 2000). Referring this definition to the above reflections, we can say that the safety system, the members of this system, their resources and needs, although invariably expressed by the same concepts, contain entirely new substance.

The actors of the security system, according to the UN documents, are no longer countries. The problems of the international community require the commitment of recourses both from national organisations, the NGOs and all other institutions of civil society. The UN takes the responsibility for setting goals leading towards better security. Regarding the measures for their implementation, however, the UN declares itself ready to cooperate with others and openly admits helplessness without their help.

There have been probably the biggest reevaluations in the UN forum in the subject of security system resources. Firstly, the focus has been moved from violent solutions to diplomatic actions. Instead of ad hoc measures, the UN attempts to implement more and more long-term solutions. The safety of an individual was made a priority, which allowed to set very specific goals for the coming years and to establish criteria on which their implementation will be assessed.

Probably the most difficult question in the UN forum is how to control the security system. If we assume that the main concern for the next few years will not be armed conflict, a concept of the UN military intervention becomes unfounded. Experience shows, however, that economic solutions and public ostracism do not produce results. Especially that the UN itself risks a financial and legislative paralysis in the near future. Advocated by the Organisation the "concept of global governance" leads us to believe that international order depends on the strength of consensus and its resilience on its multilateralism.

Given the above observations the axionormative principles of security system can no longer be the same. The difficulty lies in achieving a degree of community that would enable not only immediate but constant cooperation. Perhaps a sufficient factor for achieving it could be finding an axiological common 
ground that would allow the practical arrangements. Of course, an agreement on the common values does not necessarily have to lead to the implementation of provisions, even if they are based on them. It still needs the appropriate resources, favourable external conditions and political will.

\section{REFERENCES}

„A More Secure World: Our shared responsibility” (2004). A/59/565. High-Level Panel on Threats, Challenges and Change. In: http://www.un.org/secureworld/report2.pdf

A Plan for Action. A New Era of International Cooperation for a Changed World: 2009, 2010, and Beyond (2008), Center for International Security and Cooperation. The Brookings Institution, Washington, New York, Stanford. In: http://www.brookings.edu/reports/2008/11_action_plan_mgi.a spx

Balaban C. G. (2005): To a Global Security System. United Nations - a Global Security Organization. In: Strategic Impast. 4. Universitatea Nationala de Aparare "Carol I", Romania. 1415. In:

http://www.ceeol.com/aspx/issuedetails.aspx?issueid=500edd b5-c174-423e-af79-e569b4d8816a

Bailes A. J. K. (2004): Comments on Questions Raised in Connection with a New Political Act for United States $n$ the 21th Century. In: Rotfeld A. D. (ed.): „New Political Act for the United Nations for the 21th Century. The Polish Quarterly of International Affairs". Akademia Dyplomatyczna MSZ, Warsaw. 83.

Baylis J.-Smith S. (ed.) (2008): Globalizacja Polityki Światowej. Wprowadzenie do stosunków międzynarodowych. Wydawnictwo Uniwersytetu Jagiellońskiego, Cracow. 366.

Berdal M. (1995): The United Nations at Fifty: Its Role in Global Security. In: „IFS Info”. 3. Norwegian Institute for Defense Studies, Oslo. 16. In:

http://www.mil.no/felles/ifs/english/start/series_eng/eng_back list/eng_ifs_info/\#12

Boutros-Ghali B. (1992): ,An Agenda for Peace Preventive Diplomacy, Peacemaking and Peace-keeping". A/47/277 S/24111. In: http://www.un.org/Docs/SG/agpeace.html

Charter of the United Nations (1945). In: http://www.un.org/en/documents/charter/intro.shtml

Czaja J. (2003): The end of Westphal or the UN order. In: Krzyżanowski J. (ed.): „The United Nations: threats and challenges in the $21^{\text {st }}$ century. Conference held at the First Independent University in Poland. 22-23 March 2003". Wydawnictwo Prywatnej Wyższej Szkoły Biznesu i Administracji, Warsaw. 50.

Czaputowicz J. (2005): Bezpieczeństwo międzynarodowe po 1989 roku. In: Czaputowicz J. (ed.): „Bezpieczeństwo międzynarodowe po zakończeniu zimnej wojny. Collegium Civitas". Collegium Civitas, Warsaw. 7.

„Deputy Secretary-General addresses Panel on Human Security Marking Twentieth Anniversary of Vienna International Centre" (1999).

Press Release DSG/SM/70. In: http://www.un.org/News/Press/docs/1999/19991012.dsgsm70. doc.html

"Developments in the field of information and telecommunications in the context of international security" (1999).: Resolution adopted by

The General Assembly. A/RES/53/70. In: http://daccess-ddsny.un.org/doc/UNDOC/GEN/N99/760/03/PDF/N9976003.pdf? OpenElement
Evans G. (1994): Współpraca dla pokoju: agenda na lata dziewięćdziesiąte i następne. Wydawnictwo PISM, Warsaw. 17-18.

Frańczak O. (2004): ONZ wobec terroryzmu. In: Frańczak O., Pagórek L., Wojtowicz W. (ed.): Strategiczne aspekty walki z terroryzmem. Organizacje bezpieczeństwa międzynarodowego. Wydawnictwo Ministerstwa Obrony Narodowej, Warsaw. 10.

Friedman J. (ed.) (2003): Globalization, The State and Violence. AltaMira Press, Oxford. ix. „Global Governance. Our Global Neighborhood" The Report on The Commission on Global Governance (1995). A/50/79-S/1995/106. In: http://www.un.org/documents/ga/docs/50/plenary/a50-79.htm

Heinrich-Hamera D. (2004): Debata na temat globalizacji w Narodach Zjednoczonych. In: Haliżak E., Kuźniar R., Simonides J. (ed.): Globalizacja a stosunki międzynarodowe. Oficyna Wydawnicza BRANTA, Bydgoszcz Warsaw. 205.

„Human Development Report 1994: New Dimension of Human Security (1994). United Nations Development Program, New York. In: http://hdr.undp.org/en/reports/global/hdr1994/chapters/

„Human Development Report 2005. International cooperation at a crossroads. Aid, trade and security in an unequal Word" (2005). United Nations Development Programme, New York. In: http://hdr.undp.org/en/media/HDR05_complete.pdf

„In Larger Freedom: towards development, security and human rights for all" (2005). A/59/2005. Report of Secretary General. In: http://www.un.org/largerfreedom/executivesummary.pdf

Keohane R. O. (2002): The Globalization of Informal Violence, Theories of World Politics, and the „Liberalism of Fear”. In: „Dialog - IO”. IO Foundation and The Massachusetts Institute of Technology, Cambridge University Press. 31. In: http://journals.cambridge.org/action/displayIssue?jid=DIO\&v olumeId=1\&issueId=01\&iid=148134\#

Koziej S. (2003): The United Nations and the strategy of preemptive actions. In: Krzyżanowski J. (ed.): „The United Nations: threats and challenges in the $21^{\text {st }}$ century. Conference held at the First Independent University in Poland. 22-23 March 2003”. Wydawnictwo Prywatnej Wyższej Szkoły Biznesu i Administracji, Warsaw. 31.

Kuźniar R. (2005): Porządek międzynarodowy u progu XXI wieku. Wizje - koncepcje - paradygmaty. Wydawnictwo Uniwersytetu Warszawskiego, Warsaw. 9.

Łoś-Nowak T. (2002): Od chaosu do ładu: w poszukiwaniu nowych form organizacji stosunków międzynarodowych. In: Antoszewski A. (ed.): „Wrocławskie Studia Politologiczne”. 2. Wydawnictwo Uniwersytetu Wrocławskiego, Wrocław. 8586.

Łoś-Nowak T. (2005): The UN in the 21st Century: In search of a New Paradigm. In: Foks J. (ed.): „The Polish Foreign Affairs Digest. 5.2 (15). The Polish Institute of International Affairs, Warsaw. 43.

Malendowski W. (2000): Pokój i bezpieczeństwo międzynarodowe. In: Malendowski W., Mojsiewicz Cz. (ed.): Stosunki międzynarodowe, Wydawnictwo Atla 2. Warsaw. 401. 
Malendowski W. (2000): Nowy ład międzynarodowy. In: Malendowski W., Mojsiewicz Cz. (ed.): Stosunki międzynarodowe. Wydawnictwo Atla 2, Wroclaw. 592.

Naidu M. V. R. (1974): Collective Security and The United Nations: A Definition of The United Nations Security System. Macmillan Co. of India, Dehli. 17-19.

Orbik Z. (2005): Problematyka aksjologiczna w Karcie Narodów Zjednoczonych. In: Kapiszewski A. (ed.): „Krakowskie Studia Międzynarodowe". Wydawnictwo Krakowskiej Szkoły Wyższej, Cracow. 69.

Popiuk-Rysińska I. (1995): Ewolucja idei Narodów Zjednoczonych. In: Łoś-Nowak T. (ed.): Narody Zjednoczone między oczekiwaniem a spełnieniem. Wyd. Uniwersytetu Wrocławskiego, Wrocław. 22.

„Report of the Secretary-General on the Work of the Organization" (2000). General Assembly Official Records Fifty-fifth Session. Supplement 1 (A/55/1). New York. 4. In: http://www.un.org/documents/sg/report00/a551e.pdf

„Role of the United Nations in promoting development in the context of globalization and interdependence" (1999). Report of The Secretary General. A/RES/54/358. In: http://www.un.org/documents/ga/docs/54/plenary/a54358.htm

Rotfeld A. D. (2005): Nowy Akt Polityczny dla Narodów Zjednoczonych na XXI wiek: w poszukiwaniu nowych odpowiedzi. In: Staszków J. (ed.): „Krakowskie Studia Międzynarodowe. Karta Narodów Zjednoczonych 1945 2005”. 1 (II). Wydawnictwo Krakowskiej Szkoły Wyższej im. Andrzeja Frycza Modrzewskiego, Cracow. 14.

Rudnicki Z. (2004): The quest for improvement of the effectiveness of the UN machinery for peaceful settlement of international disputes. In: „The United Nations: threats and challenges in the XXI century. Conference held at the First Independent University in Poland". Warsaw. 44-45.
Simonides J. (2004): Narody Zjednoczone wobec wyzwań i zagrożeń XXI wieku. Między koniecznością a możliwością reformy. In: „Stosunki Międzynarodowe”. 3-4. Wydawnictwo Uniwersytetu Warszawskiego, Warsaw. 21.

Skowroński A. (1997): Siły pokojowe i operacje utrzymania pokoju Organizacji Narodów Zjednoczonych. Wydawnictwo Akademii Obrony Narodowej, Warsaw. 19-21.

Strycharz S.-Cilecki E. (2003): Niektóre problemy społeczeństwa informacyjnego u progu XXI wieku. In: Matczak O. (ed.): „Wiek XXI. Zeszyty Naukowo-Teoretyczne PWSBiA”. 1(7). Warsaw. 135-145.

„The United Nations Global Counter-Terrorism Strategy” (2006). A/RES/60/288. Adopted by General Assembly. In: http://daccess-ddsny.un.org/doc/UNDOC/GEN/N05/504/88/PDF/N0550488.pdf ?OpenElement

Thomas N.-Tow W. T. (2002): The utility of human security: sovereignty and humanitarian intervention. In: „Security Dialogue". 33. 2. 177-178. In: http://sdi.sagepub.com/content/vol33/issue2/

„United Nations Millennium Declaration” (2000). A/RES/55/2. General Assembly. In: http://www.un.org/millennium/declaration/ares552e.htm

Węgrzyn E. (2006): Wybrane koncepcje postzimnowojennego ładu światowego na przełomie XX i XXI wieku. In: Antoszewski A. (ed.): „Wrocławskie Studia Politologiczne”. 7. Wydawnictwo Uniwersytetu Wrocławskiego, Wrocław. 11.

Zięba R. (2006): System bezpieczeństwa międzynarodowego ONZ - akcje w razie zagrożenia i naruszenia pokoju. In: Simonides J. (ed.): Organizacja Narodów Zjednoczonych. Bilans i perspektywy. Wydawnictwo Naukowe SCHOLAR, Warsaw. 78. 